\title{
The Reinvention of Our Language. "material" = woman.
}

\author{
Camille Akmut
}

\begin{abstract}
The analysis of an SMS sent by a former Director of the IMF serves as the basis for a wider study on the many ways in which the elites of our days - be it the "old" of the financial or the "new" ones from the technological world - successfully define and redefine our language, and hence our thoughts. In the days of Marx and Engels, the critic of dominant ideology meant primarily a critic of the philosophical establishment (Hegel and the Young Hegelians), at a time when philosophy reigned supreme amongst disciplines. But, our days are not theirs : they present us with particular challenges, when makers of ideas (e.g. professors of economics at various leading educational institutions) are simultaneously, or successively Directors of international institutions, Ministers of Economy, leading financiers and investment bankers or quantitative analysts; the same who were, and continue to be for all those not mentioned here, involved in various crises - be it financial or otherwise (political, social, etc.) - worldwide.
\end{abstract}


"Do you wish (are you able to) come with me to Madrid and discover a hot sexy club and some new material?"

- Dominique Strauss-Kahn, former director of the IMF (International Monetary Fund), Minister of Economy, professor of economics, and many other things 


\section{Introduction}

In stark contrast with our previous studies on technology, though explicitly not unrelated to them, we draw here contrasting portraits of the "old cowboys" of the financial world and the "new" ones from the technological world.

The study of their language is a concern of prime importance : for it is ours. Their thoughts are ours. They make our thoughts, and our thoughts are made by them; because they make our language, and our language is theirs. We make a case for this in the following pages.

Making the critic of the dominant ideology, and the "false intellectuals" of our days, just as important - if not more important - as it was in the days of Marx and Engels. 


\section{Old new cowboys, New new cowboys, and the reinvention of our language}

material $=$ woman

(important note : he was not convicted, multiple times)

Connoisseur of Austrian economics, and young ("small") Viennese women based on another SMS message he sent to one of his male prostitution partners, though not of the homosexual kind or anything improper of the sort, these elites just apparently enjoy having their turn, we do not know exactly, (the same they do with countries and their people,) or perhaps it was the social aspect they treasured, it must have been that, but we just really will not know - and we wish we could say that we already knew then, what we know now, that something was fishy about him in addition to the Libertarian ideology that he taught and passed for universal science, and the false-belief, lukewarm, Clinton-style, "socialist"-only-in-name politics he practiced in the name of socialism and (false) left politics.

"The International Monetary Fund (IMF) [works] to foster global monetary cooperation, secure financial stability, facilitate international trade, promote high employment and sustainable economic growth, and reduce poverty around the world. The IMF's primary purpose is to ensure the stability of the international monetary system" (IMF site)

- this is the same institution who gets to play arbitraries of rights and wrongs among nations, and sufficient qualifications, and proper procedures, and adequate solutions (so for instance when it got to meddle in the Greek economy and simultaneously decide over the fate of that country, people), and this is the same person who headed it.

The same person who was in charge of the economy of a country, his own, France - for these elites always have a special international character to them - for years.

The same person who was - who was made to be - in charge of the education of future generations of economists for decades, and has now been quietly retired from this position. 
But, they are many others like him, and we must turn to them, if we do not want to repeat the same mistakes: Fabrice Tourre was recently made Assistant Professor, currently visiting at the University of Chicago based on the decision of a group of academics at that same (long questionable) institution (the same institution who right after his process offered him a $\mathrm{PhD}$ position in economics, because this seemed to them like the most natural thing to do). The same Fabrice Tourre who went by the nickname of "Fabulous Fab" in his wild, wild quant days at Goldman Sachs. The same who rejoiced in "embezzling orphans and widows" in messages he sent to his girlfriend, made public because the very same Fabrice Tourre stood in front of a court of law not so long ago. (His lawyers and other various fees were paid by Goldman Sachs - just like in the organized crime movies.) The same reason that made the above quoted messages public in the first place.

These gentlemen and gentlewomen, it can be said plainly at least here, if nowhere else, are the very bottom members of our society, the lowest of the lowest of hanging fruits. Marx who came from the upper classes spoke of Lumpenproletariat to describe the members of the lower classes devoid of political consciousness in somewhat condescending terms, but here is a category of individuals even below that, and they are them. (what may perhaps be called the Uppercrust)

They do what they you do with full knowledge of their actions, and their consequences, and do not have lack of education or access to education to excuse or to blame for their ways, but worst, they propagate them with the immanent authority of science and the cheap veneer neutrality of false science, but cheap veneer does not last for long.

What Huexly described in Brave New World Revisted as the real sufferers of mental illnesses, those who appear "the most normal" in our societies, for they are the best adapted to them (whereas a normal reaction to abnormal circumstances would be to be maladapted to them).

But, those who put them in positions to do so are responsible also, and we will certainty turn to them in future inquiries, if we do not, others must. They share a part of the great responsibility.

In their constant redefinition of our language, and hence our thoughts, they have convinced that middle-aged white men in suits with a bon- 
vivre nature and a penchant for red wine and meat do not belong in prison, that fresh-faced, bubbly, college graduates, also in suits, but now increasingly in t-shirts, coming from various prestigious engineering or business schools such as MIT, Stanford or Penn (so in the case of Tourre as well), are no "material" for jail.

But, it is the same people who speak freely of women as material. These "bon-vivant" who enjoy meat, indistinctively as steaks, and as women, so when they abuse their bodies in brothels, or hotels.

In their world, which is ours, because they define it, prison is only for black men. They have imprinted this notion, now turned reality, in our heads, and through so many ways, through popular books, and fiction, and Hollywood films, and TV series, now also turned reality, and not least the practices of judges and courts, that we cannot see, picture them in jail even by the best of our abilities anymore. But, by what calculations will a judge define sentences for those crimes?

The same people who are presented as perfect sons-in-law or daughtersin-law (where they use the exact same term of "material", coincidentally) in a variety of fiction works and media.

Our times, and our media, are many things, but not of Nobel Prize folk singers, blues singers singing about being miners for a heart of gold, or old Studio films like "You Can't It With You". And, so, we must, ourselves, lower ourselves, and bring ourselves, to muddle in with the excrement of our times, as the poet Baudelaire had done and proposed, for they are simultaneously the best things of our times... Not only passed as different things, but as the best.

These people not only pollute our lives, they do much worse, they polite our minds. They - them and others like them - make it hard for us to see what is right/wrong from right/wrong, because they constantly reinvent and recuperate our language to their own advantage or benefit :

So when they tell us what diversity means (recruiting often the most conservative, naive or otherwise moral-lax/free individuals within our groups to pass their messages, or do their work, and use as living vehicles of their doctrines, but only a pawn in their game, we know that being a woman or gay or otherwise does not make one progressive, 
we have been given sufficient examples of this now, unfortunately), or how loans work, or how debt gets solved, or what the best kind of altruism is (working at an investment bank...), or how a discipline should be taught, or what is permissible to research, or how to live our lives when theirs are so full of truly atrocious things. Or, indeed, that women are materials.

Not even in the worst scenes of Huxley or Orwell's visions of the future, and double-speak, was language so malleable, and dangerous. Regressive $=$ Progressive. Privacy $=$ Restriction .

Everything is upside down.

- but we are resourceful too, and use our tools, and skills, be it math, (the language of set theory, everything) or programming or statistics or history or linguistics, to defend ourselves, not -yet- to attack.

They have mastered the art of "I pat you on the back, you pat mine", having long lost sensitivity, genuinely perplexed whenever they meet people unlike themselves, but eliminating those with all much greater strength, using all of their authority and social status, given to them by the institutions that have endowed them with them, who refuse to play their games, who refuse to be pawns to their plays. People of small minds, people of sad lives. They are to be pitied, but no more. Having given up everything to get to where or what they wanted, they lost the most important in the process : everything, themselves.

We leave self-defense programs behind, so that ours will not be recuperated, neither by false intellectuals we have already described, here, and elsewhere, nor by others, however powerful. ( $\forall$.E.)

Marx spent incredible energies and an awful amount of time on the critic of the false intellectuals of his time, in the first part of his life, but, while such work is useful, and while we appreciate these writings, they are endlessly funny, because they are true, and continue to ring true even for our times, Marx, had he only dedicated his energies to the critic of intellectuals would have been at best remembered as an interesting, acute, perhaps somewhat eccentric commentator of his time (an equal or lesser Karl Krauss). We remember Marx the way we do, even despite their best efforts (so when they skip him in lectures, or do not include him in economics textbooks), as one of the 
great economists, philosophers, and intellectuals, because he wrote the Capital in addition to texts such as the aforementioned The German Ideology, and so forth (the so-called "youth writings").

But, while we believe this to be true : our days are not the days of Marx and Engels, even if parallels can be found.

For : the current makers of ideas - e.g. professors of economics at various leading educational institutions - can be and are simultaneously, or successively Directors of international institutions, Ministers of Economy, Ministers of Industry, leading financiers and investment bankers or quantitative analysists ("quants") at leading international banks.

But, we also cannot forget the complacent academics of our times, for they do not fulfill the role they should fulfill in our society, even though their voices are so greatly needed :

Their biographies, no one will write and so we write them for them, for they are generic, read : "They never took a single risk in their lives, least their intellectual lives, and lived as, and were happy academics." Boy, do they enjoy lunch with the colleagues : truly, the highlight of their day, and much of anything they will accomplish then.

Others would do anything for just one hour of glory. They are footnotes in the life of bigger men and women.

Nonetheless : There are many, many other priorities. Others are much more powerful and deserving of our attention, and work and criticism than them. And, there are many things in this world that are nothing to laugh about, and they would be only laughable if they were not things to cry over.

One historian called it "double imprisonment" : to describe the phenomenon of scholars who only write about other intellectuals, and this is all they do.

But, we must all go through our own experiences to become who we are. More importantly, we muss pass them on so that others will not err, and so they can move faster and further than we were able. 
Reading these lines they will not understand them, but this is the very nature of an imprisonment (in particular if, when it is contained as part of another one).

Courage is infectious, but so is cowardice.

In The German Ideology, Marx and Engels explain how, by owning the "means of production of ideas", the dominant classes in our societies simultaneously own ideas : our ideas, which are their ideas, and ideals.

Jeff Bezos, owner of Amazon, also owns The Washington Post.

The same Jeff Bezos who had tried to first establish Amazon - a fact that simply cannot be invented - on an Indian reservation, because as we now know establishing a business on an Indian reservation would present a business with enormous tax benefits, the same Jeff Bezos who failed to redefine an Indian reservation as a site of corporate business because the State of California intervened and broke the deal - a construct bordering on the pathological by any standard of the human mind - off. These elites, in their endless redefinitions of our language, and our thoughts, and laws, have lost any standards by which they be reminded of what could be called remotely normal.

Obviously Seattle has a great programming culture. (...) We thought about the Bay Area, which is the single best source for technical talent. But it didn't pass the smallstate test. I even investigated whether we could set up Amazon.com on an Indian reservation near San Francisco. This way we could have access to talent without all the tax consequences. Unfortunately, the government thought of that first. ${ }^{1}$

Google, owner of the dominant search platform of our times, and of the same name, a double naming standard popular with technology companies which doubly obfuscates their complex nature, and simultaneously serves to obfuscate their dominance positions (Google is

\footnotetext{
${ }^{1}$ Jeff Bezos mentions "small states" ("small"), because as we have now also learned, the smaller the population of the State, the less taxes. This is part of a 1996 interview.
} 
owned by Alphabet Inc., though the official term is "parent organization", which in turn owns series of other, connected organizations), also owns Google News, a news platform that "aggregates" - a technology world euphemism for organizes - all other news, and news media, displayed on Google - the product, we mean.

But, Google - the company, we mean again this time - owns many other products : in addition to Google (the search engine, nominally "Google Search", although no one uses this appelation, including the makers/owners, ostensibly the product iself, and by consequence its users) and Google News (a part of Google), YouTube and Android (the mobile operating system used by billions of users which includes various Google products) to name just a few.

YouTube, the current equivalent of television or the closest substitute for it, is another "aggregator" - replace organizer - of "content" that includes also various news and various news media (organizations).

They do not "aggregate" : they organize (information, including news).

They do so, organize, by using various algorithms, or classification programs, that determine how information is displayed (in what order, at what frequency, including to which, selected, public).

By creating such euphemisms, and more generally terminology, readily reused by many journalists, and ourselves, they own us too, when they do not own the journalists themselves, or in addition to doing so.

By making the product (name) coincide with the company (name), they make us forget what they truly are : not only abstract products, but companies : who may or may not pay taxes, who have business interests, who may not coincide with those of the user, and politics that may not coincide with those of democracies.

These definitions and redefinitions - terms, organizations, financial products, corporate entities, law and lawful designations - make it harder to oversee their true nature e.g. as monopoly or oligopoly.

In his introduction to The Great Crash, James Galbraith notes that 
"Largely missing from a book on the Great Crisis, 2008, will be the elements of hope, credulity, and carefree optimism that were redeeming features of the 1920s boom."

But, largely missing from our books, and all those that will need to be written from now on, are the specific turn of cruelty of our new elites. An element, that, contrary to the elites of the 1920s, it may be argued, they can draw on now based on decades of free reign, amidst impassibility from our politicians.

When they violate us - so when they threaten us with lawsuits or give us wages we cannot live on or take us in their offices where they think no one will hear, or kick us out in the streets - they violate us with all of their combined power together : their dominance over us, physical, financial, mental, social, ...

They do not only take their pleasure from violating us in one way, just physically as one may think in the case of sex workers, or only socially in the workplace, or only mentally in mental hospitals, but in all ways. They take their specific pleasure from knowing they can do it with us in all ways : side-ways, upside down, all ways, always.

Which may also explain why they take their specific enjoyment from doing their deeds in groups specifically. Reinforcing the phenomenon just described, amplifying it, until nothing is left.

Perhaps that element was already there in the elites of the $1920 \mathrm{~s}$, or perhaps they still preferred playing patriarchs, we do not know, but, no matter what, we know it is now.

And, we must ourselves use all of our energy combined to respond - not kind for kind for not only there would be no hope to win this way but there would be nothing left of our humanity - but by being much smarter than them, the only terrain where we can hope to ever surpass them. (and it is not that hard)

We cannot create capital out of nothing, and we cannot win at the game of capitals, for we have little to none, but our age presents us with tools, unavailable to previous generations, to respond in other ways, our ways. 


\section{Conclusion}

The Great Crash of 1929, 1980's Wall Street culture, 2000's Wall Street : and the tech elite that followed them ${ }^{2}$.

In the words of the economist James Galbraith :

The main relevance of The Great Crash, 1929 to the Great Crisis of 2008 is surely here. In both cases, the government knew what it should do. Both times, it declined to do it. In the summer of 1929 a few stern words from on high, a rise in the discount rate, a tough investigation into the pyramid schemes of the day, and the house of cards on Wall Street would have tumbled before its fall destroyed the whole economy. In 2004 the FBI warned publicly of "an epidemic of mortgage fraud." But the government did nothing, and less than nothing, delivering instead low interest rates, deregulation, and clear signals that laws would not be enforced.

But, let our governments and elected officials - who most of we have elected and only from us they draw their power and only by us they are permitted to occupy their temporary, not individual offices - consider what particular groups in our societies may bring on the next series of crises.

Our masters live in high towers.

These are high, but not unattainable places, and we do not only mean physical spaces : they live in adjusted construction plans, optimized tax filings, minimal up to negative corporate taxes, court proceedings from many acquittals, so-called "mistresses" - willing and unwilling, basements in London houses that are bigger than their entire surface areas, Amsterdam, Luxembourg or Ireland, our great European tax havens and our collective shame, many suites in many star hotels around the world, tailor-made suits and their tailors and their inventories and clients lists, the strange villas up in strange Dahlem, and those of even stranger Munich, the offices and the cupboards of $\mathrm{PwC}$ and the rest of the accounting consulting firms, the philanthropy contributions of various families and dynasties, the languages that they have fabricated, and all the many other places, that poison, and make all of our lives unlike what they should be.

\footnotetext{
${ }^{2}$ One third of top 25 richest people on Earth come from technology backgrounds. (Forbes Billionaires list)
} 


\section{Bibliography}

Smith, Greg. 2012. "Why I Am Leaving Goldman Sachs". The New York Times, 14/03.

Description : executive director of Goldman Sachs retires after a crisis of conscience.

Chang, Emily. 2018. Brotopia: Breaking Up the Boys' Club of Silicon Valley.

Description : excesses of the (new) new cowboys.

Wainwright, Oliver. 2012. "Billionaires' basements: the luxury bunkers making holes in London streets". The Guardian, $09 / 11$.

Description : what people with too much money and too little senses are doing with money. Also called "a-social" behaviors.

Walters, Joanna. 2018. "Meet the Sacklers: the family feuding over blame for the opioid crisis". The Guardian, 13/02.

Description : a very in-depth look at the philantropy practices, from the MET to the Tate, and MIT to Stanford, of a group of individuals - the Sacklers - whose fortune is founded in substantial parts on what can be described as "blood money" if the description of The Guardian is to be followed : their company Purdue Pharma's product OxyContin is "the pill [that] sparked the opioid crisis ... now killing more than 100 people a day in America".

Taylor, William. 1996. "Who's Writing the Book on Web Business?". Fast Company, 31/10.

Description : what may be called from now on the "Indian reservation interview". (In 1996 it seemed perfectly normal for Jeff Bezos to speak about his "Indian reservation" scheme - it must be called a scheme for it is one - but with the current backlash facing the technology world, we doubt he may find much interest in having it publicized now.) 
Leistedt, Samuel and Linkowski, Paul. 2013. "Psychopathy and the Cinema: Fact or Fiction?" Journal of Forensic Sciences 59(1) : 167-174.

Description : an interesting study on the portrayal and realism of psychopathy (arranged by categories such as "secondary", "manipulative" and "prototypical") in film, based on a sample of 400 works, including Wall Street (1987) and the main character Gordon Gekko (judged realistic).

O'Connell, Mark. 2018. "Why Silicon Valley billionaires are prepping for the apocalypse in New Zealand". The Guardian, $15 / 02$.

Description : where the (tech) elite will go once they will have had their way with our world, to the point where even they will not want to live in it anymore - or be able to live in it anymore.

Pegg, David. 2018. "From Seattle to Luxembourg: how tax schemes shaped Amazon". The Guardian, 25/04.

Description : welcome to the world of "negative" taxes (and Indian reservations...).

Galbraith, John. The Great Crash, 1929.

Description : a great book by the great economist John Galbraith, on what may be described as the "original" Crash (including an excellent introduction by James Galbraith on links with the last 2008 Crisis).

\section{Engels, Friedrich and Marx, Karl. The German Ideology.}

Description : a book we keep attributing to Marx alone, but it is a really book by Friedrich Engels as well. One person can only do so much alone. The false intellectuals of their times : Feuerbach, "Saint" Bruno, their strange ways and thoughts. But, also, more importantly, the structures of intellectual domination that make it so that elites "at any given time" - get to define and redefine our thoughts, i.e. by establishing theirs as dominant. They own us in this way too, not just economically. The relation between these two forms of domination is explained (they own "the means of production" of ideas, hence ideas). 
(If pressed by time or if only one section must/can be read, read I. Feuerbach, "Ruling Class and Ruling Ideas".)

(Every generation has their new "Feuerbach"'s, "Saint"'s and "Holy" intellectuals : the "Feuerbach of the sciences", also known as "Impenetrable Hegelian" by initials; S.Z., who we also do not name because that is how the mechanisms of (not only intellectual) stardom work, but in future writings we will only refer to him as "paradoxical (or parasitic) Feuerbach", for being an "Impenetrable Hegelian" Marxist; P.S. and W.M., whose ideas are such platitudes we were almost inclined to name, and who we are not sure if they even deserve to be called the Brothers Bauer's (or "Holy Family") of our time; etc. etc.)

Peter Thiel. https://en.wikipedia.org/wiki/Peter_Thiel

Description : "gay", "conservative libertarian".

(A combination of terms, now not unusual, that would have made anyone fall from their chairs at any of the bars involved in the Stonewall revolts. The transgender women, transgender men, the Drag Kings and Drag Queens - many of them prostitutes since they were children - would have laughed when they did not cry. The same women, men, and those who did not fit in any of the categories - because they did not have the language to say what they were, or the means to be who they knew they were - that we, me, Peter Thiel, and the rest of the Peter Thiel's of this world, owe a great debt to. That was real courage. The same that some are now trying to erase. And, we will forgo Palantir, and what a truly gruesome company that is, and the New Zealand stuff, and what the significance of New Zealand is to these (tech) elites, but we include pointers elsewhere in bibliography.)

"The IMF at a Glance". https://www.imf .org/en/About.

Description : Wolfram and Hart.

"Fabrice Tourre". https://bfi.uchicago.edu/scholar/fabrice-tourre/

Description : "Fabulous Fab", that's how he went by, back in his wild days with the ol' boys at Goldman Sachs.

Stone, Oliver. 1987. Wall Street. 